\title{
Jarosław Wierzbiński
}

Uniwersytet Łódzki, Zakład Językoznawstwa Instytutu Rusycystyki (Polska)

\section{КONCEPT „АНГЕЛ / ANIOL” W JEZZYKOWO-KULTUROWYM OBRAZIE ŚWIATA ${ }^{1}$}

W 2013 r. nakładem Wydawnictwa „Krok” w Tarnopolu ukazało się studium monograficzne Ewy Straś pt. Ангел / Anioł w ujęciu kontrastywnym rosyjsko-polskim: aspekt semantyczny $i$ etnokulturowy, wpisujące się w kontekst opracowań o charakterze interdyscyplinarnym, ale głównie w odrębną dyscyplinę naukową, jaką jest angelologia. W monografii znajdujemy pierwsze w slawistyce polskiej panoramiczne ujęcie tego tematu. Nie podejmowano dotychczas studiów w konwencji zaproponowanej przez badaczkę z podanym w tytule konceptem, co nadaje pracy nowatorski charakter. Mówiąc w tym miejscu o nowatorstwie, mam na myśli sam dobór materiału językowego i tekstowego, tryb przeprowadzonych analiz oraz ich wymierne rezultaty prezentowane w kolejnych częściach monografii.

Opracowanie bazuje na reprezentatywnej literaturze przedmiotu, zaś badany materiał językowy autorka wyekscerpowała w dużej mierze ze słowników oraz różnego rodzaju tekstów, w tym korpusów tekstów dostępnych w Internecie. Obiektem opisu staje się samo pojęcie 'anioł' i jego mentalno-wizualny obraz, przedmiotem badań zaś - warstwa semantyczna nominacji związanych $\mathrm{z}$ aniołami oraz ich funkcjonowanie w tekście. Efekty badań w znacznym stopniu determinuje obrana metodologia: autorka wykorzystała analizę definicji słownikowych, sięgając przy tym, słusznie zresztą, do analizy semowej (komponentalnej) oraz analizę tekstologiczną i porównawczą. Jej studium mieści się w nurcie kognitywistyki.

Korpus badawczy, stanowiący realizację wybranego konceptu, obejmuje dane językowe zaczerpnięte z leksykografii rosyjskiej i polskiej, w tym słowników opisowych (tzw. objaśniających), etymologicznych, historycznych, teologicznych, porównań, eufemizmów, słów skrzydlatych, synonimów, antonimów, symboli, frazeologicznych, oraz zbiorów przysłów i porzekadeł, a także słowników ency-

\footnotetext{
${ }^{1}$ Niniejszy tekst jest artykułem recenzyjnym książki Ewy Straś, której tytuł w oryginale brzmi Ангел / Aniot в русско-польском сопоставлении: семантико-этнокультурный аспект (Тернополь: Крок, 2013, 352 с.)
} 
klopedycznych. Anioł stanowi konstytutywny składnik zarówno ogólnoludzkiego systemu wartości, jak i narodowej tradycji. Tematykę anioła badaczka traktuje w wymiarze niepodważalnego faktu kultury, który reprezentowany jest przez bogactwo środków leksykalnych. Uniwersalny charakter poruszanej problematyki umożliwia przeprowadzenie analizy porównawczej w ramach pokrewnych, acz odrębnych kultur i języków. Chodzi tu wszak o dwie tradycje wizerunkowe anioła - wschodnią (anioł w prawosławiu) i zachodnią (anioł w kulturze katolickiej). Wytyczony obszar badań uwzględnia dorobek tradycyjnej leksykografii, w tym jednostki paremiologiczne wywodzące się z folkloru bądź literatury, jak i te środki realizacji badanego konceptu, które odzwierciedlają jego stan aktualny w świadomości współczesnych użytkowników języka a poświadczonych w tekstach. Tak zbudowany korpus językowy pozwala na prześledzenie drogi ewolucji konceptu 'anioł' w mentalności Rosjan i Polaków w ujęciu językoznawczym, kulturologicznym i komparatystycznym.

Termin 'koncept' funkcjonuje w językoznawstwie zarówno w ramach paradygmatu kognitywnego, jak i kulturologicznego. Oba ujęcia łączą koncept ze słowem oraz procesami myślowymi, warunkującymi istnienie czynnika subiektywnego w naturze tego zjawiska - na koncept składają się powstające w ludzkiej psychice wyobrażenia, stany emocjonalne oraz przeżycia, mające silnie zindywidualizowany charakter. Lingwistyka kognitywna definiuje koncept jako operacyjną jednostkę pamięci i obrazu świata w ludzkim umyśle, która odzwierciedla rezultaty procesów poznawczych. Podejście kulturologiczne opiera się na założeniu, iż koncept jest kondensacją kultury w mentalności człowieka; poprzez koncept użytkownik języka wchodzi w kulturę, poznaje ją i współtworzy. Tym samym koncept sytuuje się w kontekście badań nad językowym obrazem świata. Obraz ten stanowi rezultat gromadzenia wiedzy i formułowania sądów na temat rzeczywistości przez przedstawicieli określonej zbiorowości narodowej bądź etnicznej, zawarty w zasobach leksykalnych i tekstowych jej języka.

W świetle rozważań autorki, jak mogę wnioskować, za koncept uznaje się konstytutywny składnik obrazu świata, czyli wieloaspektowy konstrukt mentalny, językowy i kulturowy, ilustrowany przez kluczowe słowo nazywające taki element świata realnego bądź świata pojęć, który uchodzi za szczególnie istotny w kręgu danej społeczności. W koncepcie kumuluje się wiedza na temat wyodrębnionego fragmentu kultury, a dostęp do tej wiedzy zapewniają różnorodne środki językowe - zaliczamy do nich samodzielne słowa, związki wyrazowe, zdania oraz teksty (korpusy tekstowe). Koncept jedynie fragmentarycznie ujawnia poprzez nie swoją treść i aktualizuje cechy semantyczne ściśle determinowane przez zakres znaczeniowy reprezentujących go jednostek leksykalnych, kontekst wypowiedzi i charakter dyskursu. Dlatego, by dać możliwie pełny opis konceptu, autorka uwzględnia zróżnicowany korpus jego językowych realizacji. Treść konceptu wzbogacana jest także przez ogół tradycyjnych zachowań, praktyk, czy obrzędów, które, mimo iż przynależą do rzeczywistości pozawer- 
balnej, zostawiają swój ślad w języku lub w systemie wyznawanych przez społeczeństwo wartości i wpływają na utrwalenie danego wyobrażenia w kulturze. Toteż materiał językowo-tekstowy badaczka umiejętnie ukazała w odniesieniu do znakowych konstruktów ikonograficznych (malarskich), rzeźbiarskich, religijnych, rytualnych etc. Nawiązując do sztuki wizualnej, autorka dostrzegła wiele aspektów niewerbalnych. W jej ramie poznawczej mieszczą się nie tylko dociekania leksykograficzne, poszukiwania paremiologiczne, ale też kulturowe w szerokim tego słowa znaczeniu.

Praca składa się z szeregu uwag wstępnych, trzech rozdziałów, zakończenia bibliografii, aneksów i syntetycznego streszczenia. Słowo wstępne autorka rozpoczyna od swoistej wizualizacji postaci anioła, jakkolwiek ta z natury swojej jest nieuchwytna i ulotna. Następnie przybliża zagadnienia teoretyczne związane z pojęciem 'anioła', którego obraz poprzez wielowiekową tradycję w istotny sposób osadzony jest w językowo-kulturowym obrazie świata. Odwołuje się do takich aspektów poruszanej problematyki, jak religijne i mentalne podstawy językowego obrazu świata, dorobek leksykografii i kulturologii, uwzględniając zagadnienia kategoryzacji językowej, konceptualizacji oraz stereotypu językowego.

Rozdział I o aniołach bazuje na materiale języka rosyjskiego (s. 23-136). Badaczka przybliża w nim zagadnienia teoretyczne związane z pojęciem konceptu osadzonego w językowo-kulturowym obrazie świata. Skupiła się na szczegółowej prezentacji analitycznej 17. komponentów w strukturze analizowanego leksemu: 1) сверхъестественный, 2) бесплотный, 3) небесный, 4) идеальный, 5) служитель, 6) посредник, 7) посланец, 8) пророк; предвестник, 9) хранитель; покровитель, 10) крылатый, 11) белый, 12) красивый, 13) добрый, 14) кроткий; спокойный; терпеливый, 15) невинный, 16) веселый; беззаботный, 17) мятежный; злобный (s. 34 i nast.).

W kolejnej części rozdziału omawia przypadki przeniesienia nominacji anioła na człowieka. Analizuje m.in. określenia typu: ангел доброты, ангел красоты, ангел кротости, ангел невинности, ангел чистоты, ангел мести, ангел возмездия, ангел долготерпения (s. 92). Autorka prezentuje zatem alternatywne wcielenia anioła. Uosabia je człowiek, głównie w znaczeniu pozytywnym, ale też pejoratywnym. Następnie w sposób opisowy wizualizuje obraz anioła w realizacjach ikonicznych, na freskach, w pracach rzeźbiarskich, w ujęciach scenicznych i filmowych.

Rozdział II generuje wizerunek anioła na materiale języka polskiego (s. 137245). Autorka rozpatruje rozmaite nominacje i określenia odnoszące się do anioła, analizuje ugrupowania synonimiczne $\mathrm{z}$ tym pojęciem, rozważa kwestie etymologiczne i semantyczne nazewnictwa $z$ tego zakresu tematycznego. Omawia przynależne aniołom role i sytuuje je na tle panującej obyczajowości, uwarunkowań społeczno-historycznych oraz norm obowiązujących w relacjach ogólnoludzkich. Konwencje te przekładają się na określony status aniołów oraz sprawowane przez nie funkcje. Trudno przecenić i w tej części pracy (s. 238 i nast.) niezwykle in- 
teresujące przemyślenia i refleksje badaczki na temat wizerunku aniołów, które spotyka się na starych rysunkach, rycinach, freskach, mozaikach, ikonach, grafikach, czy też haftach. Na freskach w świątyniach i obrazach aniołowie grają na różnych instrumentach, najczęściej na lutni, skrzypcach, rogu i cytrze. Ich postacie personifikują figurki, rzeźby, statuetki i pomniki. Przedstawiane są rozmaicie: jako anioły lecące, muzykujące, modlące się; na obrazach kościelnych i płytach nagrobnych obok inskrypcji. Autorka zwraca też uwagę na anioły sceniczne i te na planie filmowym, pojawiające się przy obrzędach i świętach religijnych.

W rozdziale III autorka zestawiła obrazy anioła w obu porównywanych przestrzeniach językowych i kulturowych (s. 246-312). Omówiła m.in. model metaforycznej stopniowalności ,anioł > ideał > człowiek”. Na przykładzie wyrażeń ангел-хранитель / anioł stróż podkreśliła poszerzenie ich semantyki w socjolektach. Określiła odmienny status cherubina i serafina w polszczyźnie. Przytoczyła interesujące dane o semach w strukturze ангел / aniot, ujawniając zarówno różnice, jak też podobieństwa (por. sem 'веселый', s. 266-267). Nb. cecha ta znalazła odzwierciedlenie w kolejnych opisach, zob. s. 287-288. Badaczka wyróżniła też podobieństwa na płaszczyźnie słowotwórczej deminutywów: ангелок, ангелочек, херувимчик і aniołek, aniołeczek, cherubinek, serafinek. Interesujące są opisy przeniesienia nominacji anioła na człowieka w obu porównywanych językach: сущий, настоящий / istny, prawdziwy z ewidentną dominacją semów 'piękno' i 'dobroć'.

W Podsumowaniu podkreśliła, że znaczące podobieństwo tytułowego określenia w obu językach i kulturach jest efektem tożsamej proweniencji językowej - greckiej (łacińskiej) oraz korzeni chrześcijańskich (wschodnich i zachodnich). Nie brakuje też różnic, podkreślając przykładowo ważniejszą rolę cherubinów i serafinów w prawosławnych tekstach liturgicznych w porównaniu z tradycją katolicką. Dychotomiczny wizerunek anioła zbliża cechy duchowe z tym co materialne, świat wyobrażeń z tym co realne etc. Prawosławie i katolicyzm mają wiele punktów styczności, ale i oczywistych różnic, które manifestują się w wizerunku anioła. Temu zagadnieniu badaczka poświęciła wiele miejsca w swoim opracowaniu, podkreślając także specyfikę polskiej i rosyjskiej tradycji leksykograficznej w procesie semantyzacji leksemów anioł / ангел. Kwintesencją tego zagadnienia może być fragment opisu autorki zawarty w Streszczeniu: „Na płaszczyźnie obu języków można wykazać szereg podobieństw między eksplikacjami obrazu anioła, wynikającymi ze wspólnych chrześcijańskich korzeni, co uzasadnia zbieżną etymologię i podobieństwo semantyki jego nominacji. Tym nie mniej, oprócz wizerunkowego podobieństwa widoczne są również różnice. Wiążą się one z innym pojmowaniem anioła $\mathrm{w}$ tradycji rosyjskiej, mniejszym zdystansowaniem, większą bliskością, uwikłaniem go w folklor, mistykę, zaklęcia. Zjawiska tego nie obserwuje się w języku polskim, gdzie anioł jest częściej uduchowiony i wyniosły, a przez to bardziej odległy i jakby mniej zaangażowany w codzienne sprawy ludzkie" (s. 350). 
Literatura przedmiotu podana w Bibliografii uwzględnia zarówno kluczowe pozycje, jak też dodatkowe opracowania związane z tematyką pracy w obu obszarach językowych. W mojej ocenie praca napisana jest wzorcową ruszczyzną z uwzględnieniem reprezentatywnego i umiejętnie podanego aparatu terminologicznego. Opisom aniołów towarzyszą tablice, co dobrze porządkuje wiedzę z tego zakresu (zob. ss. 26-27, 29; 140-141, 144). Rezultaty przeprowadzonych w książce analiz zostały ponadto usystematyzowane w czterech aneksach, będących tabelarycznym zestawieniem leksemów i określeń: pierwszy odzwierciedla ekwiwalentną hierarchię w nominacji aniołów (Серафимы / Serafini, Херувимы / Cherubini itd., s. 335), drugi jest ilustracją właściwości i zachowań anioła jako istoty duchowej (zob. np. opis dla wyróżnionych cech 'кроткий, спокойный, терпеливый’: ангельское терпение; тихий ангел пролетел / anielska cierpliwość; anielski spokój; cisza jakby anioł przeleciał, s. 339), trzeci uwzględnia przeniesienie cech anioła na człowieka (por. m.in. opis cechy 'добрый': ангел доброты; добр / добрый как ангел; (как) добрый ангел, ангел милосердия / aniot dobroci, dobry jak anioł (niebieski); być czyimś dobrym aniołem; anielica; dobry jak aniot, (czyjś) dobry aniot, s. 342), czwarty podaje materialne uosobienie anioła (por. np. w części скульптуры и фигуры: ангель-хранители смотрят с баллюстрады собора; ангел на Петропавловской крепости ... / Aniot Ciszy; Frunie aniot śmierci ..., s. 345-346).

Walory naukowe, poznawcze i dydaktyczne monografii Ewy Straś jednoznacznie sytuują opiniowaną pracę pod względem merytorycznym i językowym w rzędzie znaczących i wartościowych pozycji w dorobku polskiej slawistyki.

\author{
Jarostaw Wierzbiński
}

\title{
THE CONCEPT OF «AHГEЛ / ANGEL» IN THE LINGUA-CULTURAL PICTURE OF THE WORLD
}

\author{
(Summary)
}

The present text is the review article of the book of Ewa Straś entitled Ангел / Angel in the Russian-Polish comparison: semantico-ethnocultural aspect (Ternopil, Krok, 2013, 352 pp.). In Polish Slavistics the monograph is recognised as the first work that shows the panoramic approach to the concept. The main attention is focused on the semantic aspect of names connected with angels and their functioning in text. The topic of angels is treated by the author as a phenomenon of culture, represented by the richness of lexical means. She presents the picture of angel in both compared linguistic and cultural areas, taking into consideration similarities as well as differences in their images.

Keywords: concept of «angel», language and culture, the Russian - Polish comparative aspect. 


\section{КONCEPT „АНГЕЛ / ANIO૯” W JEZZYKOWO-KULTUROWYM OBRAZIE ŚWIATA}

\section{(Streszczenie)}

Niniejszy tekst jest artykułem recenzyjnym książki Ewy Straś pt. Ангел / Anioł в русско-польском сопоставлении: семантико-этнокультурный аспект (Тернополь: Крок, 2013, 352 c.). W slawistyce polskiej monografia ta stanowi pierwsze panoramiczne ujęcie wskazanego konceptu. Przedmiotem badań jest warstwa semantyczna nominacji związanych z aniołami oraz ich funkcjonowanie w tekście. Tematykę anioła badaczka traktuje w wymiarze fenomenu kultury, który reprezentowany jest przez bogactwo środków leksykalnych. Autorka zestawiła obrazy anioła w obu porównywanych przestrzeniach językowych i kulturowych wskazując zarówno na podobieństwa, jak i różnice w ich wizerunkach.

Słowa kluczowe: koncept ,, aniol”, język i kultura, aspekt porównawczy rosyjsko-polski. 